\title{
PENGATURAN PENGANGKATAN SEKRETARIS DAERAH UNTUK MEWUJUDKAN NETRALITAS PEGAWAI NEGERI SIPIL DAERAH
}

Oleh :

I Gede Pranajaya ${ }^{1}$

\begin{abstract}
Governance and development efforts to implement national and local levels can run smoothly largely depends on the perfection of the State apparatus, which in its function must be professional and neutral character of the influence of all groups and political parties, and does not discriminate in providing services to the community in order to realize the welfare of society. To realize the neutrality of the State Apparatus, the central government is trying to give a neutral space of the apparatus of government both at central and local levels, however, the reality is often found to realize it is not easy. Various allegations of lack of neutrality of State Apparatus including regional secretary still often expressed by the public, especially during the General Election of Regional Head and Deputy Head of the candidates came from previously elected regional head (incumbent). It is not separated from the vagueness of the norm (vogue norm), associated with the filling of the post of secretary of the province are included in the Position Leader High as stipulated in Article 19 paragraph (3) of Law No. 5 of 2014 on the Reform of Civil State, stating for High leadership positions defined competency requirements, qualifications, rank, education and training, track record position and integrity, as well as other necessary requirements. The above provisions are not clear in stating the requirements that must be met by candidates for secretary of the province to ensure neutrality. This study is a normative law research that examines the ingredients literature that primary legal materials and secondary law. This study uses the approach of legislation and approach the concept. In the data collection is done by steps searches theories, concepts, principles, and an inventory of rule of law relating to the research problem. The conclusion relating to the cases in this study, namely charging Position Leader Higher done in an open and competitive among Civil Servants by taking into account the requirements of competence, qualifications, rank, education and training, track record positions, and intergitas and other requirements needed in accordance with the legislation reflects to realize the secretaries of provincial officials were neutral.
\end{abstract}

Keywords: neutrality, competence, Position openly charging

\section{PENDAHULUAN}

\subsection{Latar Belakang}

Undang-Undang Dasar Negara

Republik Indonesia Tahun 1945 Pasal 1 ayat (1) menegaskan Negara Indonesia ialah Negara Kesatuan berbentuk Republik.

Mahasiswi Magister Ilmu Hukum Universitas Udayana, Denpasar, Bali, Alamat Jalan Gurita 4 no 8A Denpasar Bali, e-mail: gedepranajaya21@gmail. com@gmail.com
Dalam Negara Kesatuan Republik Indonesia kedaulatan negara adalah tunggal, artinya Pemerintah Pusat memegang kekuasaan secara penuh. Namun mengingat Negara Indonesia sangat luas terdiri dari atas puluhan ribu pulau besar dan kecil, dan penduduknya terdiri dari beragam suku bangsa, beragam etnis, beragam golongan, dan memeluk agama yang berbeda-beda maka tidak mungkin jika segala sesuatunya 
diurus seluruhnya oleh Pemerintah Pusat yang berkedudukan di ibukota negara. Sehingga untuk mengurus penyelenggaraan pemerintahan negara sampai kepada seluruh pelosok daerah maka perlu dibentuk suatu pemerintahan daerah, sesuai dengan amanat Undang-Undang Dasar Negara Republik Indonesia Tahun $1945 .^{2}$

Pemerintahan Daerah dalam Negara Kesatuan merupakan satu kesatuan dengan Pemerintahan Nasional. Suatu Negara disebut kesatuan, apabila dalam lingkungan Negara itu terdapat daerah yang disebut Negara. ${ }^{3}$ Negara Kesatuan adalah Negara tunggal, Negara yang terdiri dari satu Negara saja, betapapun besar dan kecilnya. Hubungan kedalam maupun keluar adalah kesatuan. ${ }^{4}$ Sejalan dengan itu, kebijakan yang dibuat dan dilaksanakan oleh Pemerintah Daerah merupakan bagian dari urusan negara yang dilaksanakan oleh Pemerintah Pusat. Pembedanya adalah terletak pada bagaimana memanfaatkan kearifan, potensi, inovasi, daya saing, dan kreatifitas Daerah untuk mencapai tujuan nasional di tingkat lokal yang pada gilirannya akan mendukung pencapaian tujuan nasional secara keseluruhan sebagaimana diamanatkan pada Pembukaan Undang-Undang Dasar Negara Republik Indonesia Tahun 1945 adalah melindungi segenap Bangsa Indonesia dan seluruh Tumpah Darah Indonesia dan memajukan kecerdasan kehidupan Bangsa dan ikut melaksanakan ketertiban dunia yang berdasarkan kemerdekaan, perdamaian

Sunarno Siswanto, 2012, Hukum Pemerintahan Daerah, Sinar Grafika, Jakarta, hlm.54.

Ellydar Chaidir, 2008, Sistem Pemerintahan Negara Republik Indonesia, Pasca Perubahan UndangUndang Dasar 1945, Total Media, Yogyakarta, hlm.57.

4 Busrizalti, H.M, 2013, Hukum Pemda, Otonomi, dan Implikasinya, Total Media, Jakarta, hlm.18. abadi, dan keadilan sosial. Tujuan nasional tersebut hanya dapat tercapai melalui pembangunan yang bertujuan untuk meningkatkan kesejahteraan masyarakat dan membangun kehidupan demokrasi yang lebih baik. Kelancaran penyelenggaraan pemerintahan dan pelaksanaan pembangunan nasional itu terutama sekali tergantung pada kesempurnaan Aparatur Negara. ${ }^{5}$ Kesempurnaan Aparatur Negara pada pokoknya tergantung dari kesempurnaan pegawai negeri. Sementara itu, demokrasi yang dimaksud adalah pemerintahan yang menjamin dan lebih berpihak pada rakyat, memberikan kemerdekaan yang nyata kepada rakyat dalam menyampaikan aspirasinya dalam kehidupan politik bangsa dengan tanpa adanya tekanan politik atau politik yang merugikan rakyat.

Untuk dapat mewujudkan netralitas pemerintahan baik di di tingkat di pusat maupun di tingkat daerah sudah merupakan tekad dari pemerintah, mengingat netralitas Aparatur Negara sangat dibutuhkan bagi organisasi pemerintahan yang misi utamanya adalah mengatur dan melayani dan memberdayakan masyarakat agar terwujud kesejahteraan masyarakat. Ketidaknetralan juga akan menyebabkannya kacaunya manajemen kepegawaian, tidak berjalannya pola karier yang benar karena didominasi oleh unsur kekuasaan, serta penyelenggaraan pemerintahan yang jauh dari profesionalisme. Penegasan yang mengarahkan netralitas aparatur pemerintahan dituangkan dalam Pasal 9 ayat (2) Undang-Undang Nomor 5 Tahun 2014 tentang Aparatur Sipil Negara, disebutkan

Hartini, Sri Setajen Kadarsih dan Sudrajat Tedi, 2010, Hukum Kepegawaian di Indonesia, Sinar Grafika, Jakarta, hlm.98. 
bahwa Pegawai Aparatur Sipil Negara harus bebas dari pengaruh dan intervensi semua golongan dan partai politik. Berdasarkan ketentuan tersebut Pegawai Aparatur Sipil Negara sebagai unsur aparatur negara harus netral dari pengaruh semua golongan dan Partai Politik, dalam memberikan pelayanan kepada masyarakat harus berlaku adil dan netral. Ketentuan ini berlaku bagi seluruh aparatur pemerintahan baik yang berada di tingkat pusat maupun daerah termasuk sekretaris daerah provinsi yang merupakan jabatan karier tertinggi pada pemerintah daerah. Namun dalam realitanya tidaklah mudah untuk mewujudkan netralitas pada aparatur pemerintahan ini. Berbagai tudingan ketidaknetralan sekretaris daerah, termasuk di Daerah Bali masih sering dikemukakan masyarakat melalui media massa terutama pada waktu pemilihan umum kepala daerah dan wakil kepala daerah yang salah satu calonnya berasal dari kepala daerah sebelumnya (incumbent). Dengan kata lain tidak jarang jabatan sekretaris daerah diisi oleh orang-orang yang mempunyai hubungan politik yang kuat dengan partai politik atau berjasa dengan kepala daerah terpilih dalam pemilihan kepala daerah dan wakil kepala daerah. Para Tim Sukses dari Pegawai Negeri Sipil sudah barang tentu mendapat imbalan/kompensasi dari yang telah dilakukannya.

Secara normatif fenomena seperti tersebut di atas tidak terlepas dari terjadinya kekaburan norma terkait dengan pengisian jabatan sekretaris daerah provinsi yang merupakan jabatan eselon I.b, dimana sesuai dengan Pasal 131 Undang-Undang Nomor 5 Tahun 2014 tentang Aparatur Sipil Negara, setara dengan jabatan pimpinan tinggi madya. Berdasarkan Pasal 108 ayat
(1) Undang-Undang Nomor 5 Tahun 2015 tentang Aparatur Sipil Negara, ditentukan bahwa pengisian jabatan pimpinan tinggi utama dan madya pada kementerian kesekretariatan lembaga negara, lembaga non struktural,dan instansi daerah dilakukan dikalangan PNS dengan memperhatikan syarat kompotensi, kualifikasi, kepangkatan, pendidikan dan latihan, rekam jejak jabatan, dan integritas serta persyaratan lainnya yang dibutuhkan sesuai dengan ketentuan peraturan perundang-undangan. Di dalam ketentuan tersebut di atas tidak mengatur secara tegas mengenai syarat-syarat yang wajib dipenuhi oleh calon sekretaris daerah provinsi yang dapat menjamin netralitasnya. Oleh karena itu perlu dilakukan pengkajian mengenai permasalahan diatas yang selanjutnya akan diuraikan didalam karya ilmiah ini.

\subsection{Rumusan Masalah}

Berdasarkan pemaparan latar belakang diatas, dapat dirumuskan permasalahan sebagai berikut:

1. Produk hukum apakah yang mengatur pengangkatan pejabat dalam pengisian jabatan sekretaris daerah provinsi?

2. Persyaratan apakah yang harus diatur dalam peraturan perundang-undangan terkait dengan pengangkatan pejabat sekretaris daerah provinsi untuk dapat mewujudkan pejabat Sekretaris Daerah Provinsi yang netral?

\subsection{Tujuan Penelitian}

Secara umum, penelitian bertujuan untuk pengembangan ilmu hukum terutama bidang Hukum Administrasi, Hukum Pemerintahan Daerah dan Hukum Kepegawaian yang berkaitan dengan 
pengangkatan sekretaris daerah dalam upaya mewujudkan netralitas Pegawai Negeri Sipil Daerah.

Adapun tujuan khususnya adalah untuk mengkaji dan menganalisis persyaratan yang ditentukan dalam Peraturan PerundangUndangan terkait dengan pengangkatan Jabatan Sekretaris Daerah Provinsi telah mencerminkan upaya mewujudkan pejabat sekretaris daerah provinsi yang netral atau belum.

\section{METODE PENELIAN}

Metode yang digunakan dalam Penelitian ini adalah dengan penelitian hukum normatif. Didalam melakukan penelitian normatif, maka akan memulai dari suatu peristiwa hukum dan selanjutnya akan dicari rujukan pada sistem norma, seperti peraturan perundang-undangan, asasasas hukum maupun doktrin-doktrin hukum yang diajarkan para ahli untuk mencari konstruksi hukum maupun hubungan hukum. ${ }^{6}$ Sesuai dengan permasalahan yang dikaji maka pendekatan yang dipergunakan adalah pendekatan perundang-undangan dan pendekatan konseptual.

Adapun sumber bahan hukum yang dipergunakan dalam penelitian hukum normatif, mempergunakan bahan hukum primer dan sekunder. ${ }^{7}$ Bahan hukum primer terdiri dari beberapa jenis peraturan perundang-undangan khususnya yang mengatur mengenai pengangkatan sekretaris daerah provinsi dan netralitas aparatur sipil negara.

Mukti Fajar Nd \& Yulianto Achmad, 2010, Dualisme Penelitian Hukum Normative \& Empiris, Pustaka Belajar, hlm.36

Johny Ibrahim, 2011, Teori dan Metode Penelitian Hukum Normatif, Banyumedia Publishing, Malang, hlm.57.
Sedangkan bahan hukum sekunder yang digunakan meliputi buku-buku ataupun literatur-literatur hukum, jurnal-jurnal hukum, pendapat para sarjana yang relevan dengan permasalahan yang diteliti.

Keseluruhan bahan hukum tersebut dikumpulkan dengan mempergunakan studi kepustakaanyangkemudiandianalisis dengan teknik deskripsi dan teknik interprestasi. ${ }^{8}$

\section{HASIL DAN PEMBAHASAN}

\subsection{Produk Hukum yang Mengatur Pengangkatan Pejabat dalam pengisian jabatan Sekretaris Daerah Provinsi}

Jimly Asshiddiqie mengemukakan bahwa Indonesia adalah negara hukum. ${ }^{9}$ Dianutnya negara hukum di Indonesia ditegaskan dalam Pasal 1 ayat (3) UndangUndang Dasar Negara Republik Indonesia Tahun 1945 yang menyatakan Negara Indonesia adalah negara hukum. Hal ini berarti, bahwa Negara Indonesia dalam melaksanakan aktivitas kenegaraannya harus berdasarkan hukum yang berlaku. Secara Konstitusional Negara Indonesia menganut prinsip Negara Hukum yang dinamis atau welfare state, dengan demikian tugas pemerintah begitu luas. Pemerintah wajib memberikan perlindungan kepada masyarakat yang salah satunya di bidang hukum. ${ }^{10}$

Anonim, 2013, Pedoman Penulisan Usulan Penelitian Tesis dan Penulisan Tesis Program Studi Magister (S2) Ilmu Hukum, Program Studi Magister (S2) Ilmu Hukum Program Pascasarjana Universitas Udayana, hlm.30.

9 Jimly Asshiddiqie, 2010, Konstitusi dan Konstitusionalisme Indonesia, Sinar Grafika, Jakarta, hlm.132.

10 SF. Marbun dan Moh. Mahfud MD, 2009, Pokok-Pokok Hukum Administrasi Negara, Liberty, Yogyakarta, hlm.52. 
Prinsip Negara Hukum di Indonesia juga dikemukakan oleh Anwar $\mathrm{C}$, yang menyatakan bahwa unsur Negara Hukum Indonesia, yaitu :

a. Ada UUD yang minimal mengatur pembagian dan pembatasan kekuasaan dalam Negara, adanya perlindungan HAM.

b. Supremasi Hukum (Supremacy of Law).

c. Persamaan dalam hukum (Due Proces of law).

d. Peradilan bebas dan tidak memihak.

e. Peradilan Tata Usaha Negara.

f. Peradilan TataNegara(Constitutional Court).

g. Perlindungan hukum terhadap Hak Asasi Manusia.

h. Bersifat demokrasi (Democratitiehe Rechstaat). ${ }^{11}$

Dengan dianutnya negara hukum maka pemerintah dan lembaga-lembaga negara yang lain dalam melaksanakan tindakan apapun harus dilandasi hukum atau harus dapat dipertanggungjawabkan secara hukum. Sesuai denga pendapat A. Hamid S. Atamimi, yang menyatakan Indonesia adalah Negara berdasarkan atas Hukum (Rechtstaat). ${ }^{12}$ Menurut Burken bahwa suatu negara dapat dikatakan sebagai negara hukum (rechtaat) apabila memenuhi syarat-syarat:

1. Azas legalitas. Setiap tindakan pemerintahan harus didasarkan atas peraturan perundang-undangan (watterlijk gronslag. Dengan landasan

11 Anwar C, 2011, Teori dan Hukum , Konstitusi, Paradigma Kedudukan dalam UUD 1945 Implikasi dan Implementasinya pada Lembaga Negara, Instrans Publishing, Malang, hlm.57.

12 Dasril Radjab, 2005, Hukum Tata Negara Indonesia, Rineka Cipta, Jakarta, hlm.27. ini, undang-undang sendiri merupakan tumpuan dasar tindak pemerintahan. Dalam hubungan ini pembentukan undang-undang merupakan bagian penting dari negara hukum.

2. Pembagian kekuasaan. Syarat ini mengandung makna bahwa kekuasaan negara tidak boleh hanya bertumpu pada satu tangan.

3. Hak-hak dasar (grondrechten), merupakan sasaran perlindungan dari pemerintahan terhadap rakyat dan sekaligus membatasi kekuasaan pembentuk undang-undang.

4. Pengawasan pengadilan bagi rakyat tersedia.

Sesuai dengan syarat-syarat dapat disebutnya sebagai negara hukum dari Burken pada syarat pertama yaitu azas legalitas, apabila dikaitkan dengan pengangkatan sekretaris daerah provinsi diwujudkan dalam bentuk undang-undang dan peraturan perundang-undangan lainnya yang mengatur pengangkatan sekretaris daerah provinsi. Sehubungan dengan azas legalitas dalam pengangkatan sekretaris daerah provinsi diatur dalam UndangUndang Nomor 5 Tahun 2014 tentang Aparatur Sipil Negara, Peraturan Pemerintah Nomor 13 Tahun 2002 tentang Perubahan atas Peraturan Pemerintah Nomor 100 Tahun 2000 tentang Pengangkatan Pegawai Negeri Dalam Jabatan Struktural dan Peraturan Menteri Pendayagunaan Aparatur Negara dan Reformasi Republik Indonesia Nomor 13 Tahun 2014 tentang Tata Cara Pengisian Jabatan Pimpinan Tinggi Secara Terbuka Dilingkungan Instansi Pemerintah. Jabatan Struktural adalah kedudukan yang menunjukkan tugas dan tanggung jawab, wewenang dan hak seorang PNS 
dalam rangka memimpin suatu organisasi. Pengangkatan Pegawai Negeri Sipil (PNS) dalam jabatan struktural antara lain dimaksudkan untuk membina karier PNS dalam jabatan struktural dan kepangkatan sesuai dengan persyaratan yang ditetapkan dalam peraturan perundang-undangan. Sekretaris daerah provinsi adalah jabatan eselon Ib yang merupakan jabatan struktural tertinggi pada pemerintah daerah provinsi, yang berdasarkan Undang-Undang Nomor 5 Tahun 2014 tentang Aparatur Sipil Negara, eselon Ib setara dengan jabatan pimpinan tinggi madya. Mengenai Pengangkatan Jabatan pimpinan tinggi madya diatur dalam Pasal 19 ayat (3) Undang-Undang Nomor 5 Tahun 2014 tentang Aparatur Sipil Negara, disebutkan bahwa untuk setiap jabatan pimpinan tinggi ditetapkan syarat kompotensi, kualifikasi, kepangkatan, pendidikan dan pelatihan, rekam jejak jabatan dan integritas, serta peryaratan lain yang dibutuhkan.

Selanjutnya mengenai pengisian jabatan pimpinan tinggi madya di instansi daerah diatur dalam Pasal 114 UndangUndang Nomor 5 Tahun 2014 tentang Aparatur Sipil Negara sebagai berikut:

(1) Pengisian jabatan pimpinan tinggi madya di tingkat provinsi dilakukan oleh pejabat Pembina kepegawaian dengan terlebih dahulu membentuk panitia seleksi.

(2) Panitia seleksi sebagaimana dimaksud pada pimpinan tinggi madya untuk setiap 1 (satu) lowongan jabatan.

(3) Tiga calon nama pejabat pimpinan tinggi madya yang terpilih sebagaiman dimaksud pada ayat (2) disampaikan kepada pejabat Pembina kepegawaian.

(4) Pejabat Pembina kepegawaian mengusulkan3(tiga)namacalonpejabat pimpinan tinggi madya sebagaimana pada ayat (3) kepada Presiden melalui menteri yang menyelenggarakan urusan pemerintahan dalam negeri.

(5) Presiden memilih 1 (satu) nama dari 3 (tiga) nama calon yang disampaikan untuk ditetapkan sebagai pimpinan tinggi madya.

Lebih lanjut di dalam Pasal 5 Peraturan Pemerintah Nomor 100 Tahun 2000 tentang Pengangkatan Pegawai Negeri Sipil Dalam Jabatan Struktural, ditentukan bahwa peryaratan Pegawai Negeri Sipil yang akan diangkat dalam jabatan struktural, antara lain: berstatus Pegawai Negeri Sipil, serendah-rendahnya memiliki pangkat satu tingkat di bawah jenjang pangkat yang ditentukan, memiliki kualifikasi dan tingkat pendidikan yang ditentukan, semua unsur penilaian prestasi kerja bernilai baik dalam dua tahun terakhir, memiliki kompotensi jabatan yang diperlukan, sehat jasmani dan rohani. Pengisian jabatan pimpinan tinggi secara terbuka diatur dalam Peraturan Menteri Pendayagunaan Aparatur dan Reformasi Birokrasi Nomor 13 Tahun 2014 tentang Tata Cara Pengisian Jabatan Pimpinan Tinggi Secara Terbuka Di Lingkungan Instansi Pemerintah, di mana dalam lampirannya antara lain disebutkan berdasarkan Undang-Undang Nomor 5 Tahun 2014 tentang Aparatur Sipil Negara, antara lain mengamanatkan bahwa pengisian jabatan pimpinan tinggi utama dan madya pada kementerian, kesekretariatan lembaga negara, lembaga nonstruktural, dan instansi Daerah dilakukan secara terbuka dan kompetitif di kalangan PNS dengan memperhatikan syarat kompetensi, 
kualifikasi, kepangkatan, pendidikan dan latihan, rekam jejak jabatan, dan integritas serta peryaratan lain yang dibutuhkan sesuai dengan ketentuan peraturan perundang-undangan dan dilakukan pada tingkat nasional. Pada dasarnya Peraturan Menteri Pendayagunaan Aparatur Negara dan reformasi Birokrasi Nomor 13 Tahun 2014 tersebut merupakan pedoman bagi Pemerintah baik di Pusat maupun Daerah dalam melaksanakan Undang-Undang Nomor 5 Tahun 2014 tentang Aparatur Negara khususnya mengenai pengisian jabatan pimpinan tinggi utama dan madya termasuk sekretaris daerah provinsi yang merupakan jabatan pimpinan tinggi madya di daerah provinsi. Oleh karena itu, secara subtansi dalam pengisian jabatan sekrtetaris daerah provinsi harus berpedoman pada Peraturan Menteri Pendayagunaan Aparatur dan Reformasi Birokrasi Nomor 13 Tahun 2014 tentang Tata Cara Pengisian Jabatan Pimpinan Tinggi Secara Terbuka di Lingkungan Instansi Pemerintah.

Peraturan perundang-undangan tersebut diatas, adalah merupakan landasan hukum yang ditetapkan oleh Pemerintah dalam pengangkatan sekretaris daerah provinsi, dan dengan diaturnya pengangkatan sekretaris daerah provinsi dalam suatu produk hukum akan dapat dihindarinya tindakan sewenang-wenang dari pemerintah atau badan yang mempunyai kewenangan dalam pengangkatan sekretaris daerah provinsi.

\subsection{Persyaratan yang Menjamin Netralitas dalam pengangkatan Pejabat Sekretaris Daerah Provinsi}

Berbicara mengenai netralitas birokrasi telah ditegaskan dalam Pasal 9 ayat (2) Undang-Undang Nomor 5 Tahun
2014 tentang Aparatur Sipil Negara yang menyebutkan bahwa Pegawai Aparatur Sipil Negara harus bebas dari pengaruh dan intervensi semua golonagan dan partai politik. Ketentuan tersebut merupakan perwujudan kebijakan dan manajemen Aparatur Sipil Negara (ASN) yang menganut asas netralitas, yakni untuk menciptakan pegawai Aparatur Sipil Negara yang profesional dan berkinerja, sehingga dapat memberikan pelayanan secara adil dan netral menjadi perekat dan pemersatu bangsa. Maka dari itu untuk dapat menjalankan tugas pelayanan publik, tugas pemerintahan, dan tugas pembangunan profesi dan manajemen Pegawai Aparatur Sipil Negara berdasarkan pada Sistem Merit atau perbandingan antara kualifikasi, kompetensi, dan kinerja yang dimiliki oleh calon dalam rekruitment, pengangkatan, penempatan, dan promosi pada jabatan yang dilaksanakan secara terbuka dan kompetitif, sejalan dengan tata kelola pemerintahan yang baik.

Pengangkatan Pegawai Negeri Sipil dalam jabatan merupakan salah satu bagian dari kebijakan dalam manajemen Pegawai Negeri Sipil. Pada penjelasan lebih lanjut, jabatan adalah kedudukan yang menunjukkan tugas dan tanggungjawab, wewenang dan hak seorang Pegawai Negeri Sipil dalam suatu jabatan dalam suatu organisasi negara. Pada pengangkatan dalam jabatan dikenal dengan adanya istilah jabatan karier. Jabatan karier merupakan jabatan struktural dan fungsional yang hanya dapat diduduki oleh Pegawai Negeri Sipil setelah memenuhi syarat yang ditentukan.

Selanjutnya Jabatan struktural merupakan kedudukan yang menunjukkan tugas, tanggung jawab, wewenang dan hak seorang Pegawai Negeri Sipil dalam 
memimpin satuan organisasi negara. Pengangkatan Pegawai Negeri Sipil dalam jabatan Struktural antara lain dimaksudkan untuk membina karier Pegawai Negeri Sipil dalam jabatan sesuai dengan persyaratan yang ditetapkan dalam peraturan perundangundangan yang berlaku Mengenai Pengangkatan Pegawai Negeri Sipil Dalam jabatan tertentu diatur dalam Pasal 68 ayat (2) Undang-Undang Nomor 5 Tahun 2014 tentang Aparatur Sipil Negara, dimana didalamnya menyebutkan bahwa pengangkatan Pegawai Negeri Sipil dalam jabatan tertentu berdasarkan perbandingan obyektif antara kompetensi, kualifikasi, dan peryaratan yang dibutuhkan oleh jabatan dengan kompetensi, kualifikasi, dan persyaratan yang dimiliki oleh pegawai. Lebih lanjut untuk pengangkatan Pegawai Negeri Sipil dalam jabatan pimpinan tinggi madya pada daerah provinsi, yaitu sekretaris daerah provinsi berdasarkan Pasal 108 ayat (1) Undang-Undang Nomor 5 Tahun 2014 tentang Aparatur Sipil Negara, dilakukan secara terbuka dan kompetitif di kalangan Pegawai Negeri Sipil dengan memperhatikan syarat kompetensi, kualifikasi, kepangkatan, pendidikan dan latihan, rekam jejak jabatan, integritas serta peryaratan lain yang dibutuhkan sesuai dengan ketentuan peraturan perundangundangan. Untuk pengisian jabatan struktural sekretrais daerah provinsi diatur dalam Pasal 114 Undang-Undang Nomor 5 Tahun 2014 tentang Aparatur Sipil Negara, yaitu Pembina Kepegawaian yang kalau di daerah provinsi adalah gubernur mengambil langkah-langkah dengan membentuk Panitia Seleksi (Pansel), dimana Panitia Seleksi (pansel) memilih 3 (tiga) nama calon untuk lowongan tersebut dan disampaikan kepada Penjabat Pembina Kepegawaian dan selanjutnya Penjabat Pembina Kepegawaian mengusulkan 3 (tiga) nama calon pejabat pimpinan tinggi madya tersebut kepada Presiden melalui Menteri Dalam Negeri. Lebih lanjut Presiden dibantu oleh Tim memilih 1 (satu) nama dari 3 (tiga) nama calon yang disampaiakan untuk ditetapkan sebagai pejabat pimpinan tinggi madya atau sekretaris daerah provinsi.

Melalui yang mekanisme yang dilakukan secara terbuka yang dapat diikuti oleh seluruh Pegawai Negeri Sipil yang memenuhi syarat untuk dapat diangkat dalam jabatan struktural sekretaris daerah, serta melalui Panitia Seleksi (Pansel) yang dibentukolehPenjabatPembinaKepegawaian kewenangan Penjabat Kepegawaian Daerah hanya mengusulkan 3 (tiga) nama dari hasil pilihan yang disampaikan Panitia Seleksi (Pansel) kepada Presiden melalui Menteri Dalam Negeri untuk ditetapkan salah satunya sebagai sekretaris daerah provinsi, akan menjamin seorang penjabat sekretaris daerah yang netral dalam melaksanakan tugas, wewenang dan kewajibannya sebagai seorang sekretaris daerah.

\section{PENUTUP}

\subsection{Simpulan}

Berdasarkan pembahasan seperti yang telah diuraikan di atas, maka dapat diambil suatu simpulan sebagai berikut :

1. Produk hukum yang mengatur pengangkatan jabatan sekretaris daerah provinsi yang merupakan jabatan pimpinan tinggi madya diatur dalam Pasal 19 ayat (3) Undang-Undang Nomor 5 Tahun 2014 tentang Aparatur Sipil Negara, yang menyebutkan bahwa untuk setiap jabatan pimpinan 
tinggi ditetapkan syarat kompetensi, kualifikasi, kepangkatan, pendidikan dan pelatihan, rekam jejak jabatan dan integritas serta persyaratan lain yang dibutuhkan sesuai dengan peraturan perundang-undangan, dan Pasal 13 ayat (3) Peraturan Pemerintah Nomor 3 Tahun 2003 tentang Wewenang Pengangkatan, Pemindahan dan Pemberhentian Pegawai Negeri Sipil yang diangkat dalam jabatan struktural harus memenuhi syarat untuk diangkat dalam jabatan struktural.

2. Pengangkatan sekretaris daerah provinsi yang merupakan jabatan pimpinan tinggi madya, ditetapkan berdasarkan kompetensi, kualifikasi, kepangkatan, pendidikan dan pelatihan, rekam jejak jabatan dan integritas, serta persyaratan lain yang dibutuhkan, dan mekanismenya melalui seleksi terbuka bagi seluruh Pegawai Negeri Sipil dalam lingkup wilayah provinsi yang memenuhi syarat untuk dapat diangkat sebagai pejabat struktural sekretaris daerah provinsi telah mencerminkan upaya mewujudkan penjabat sekretaris daerah provinsi yang netral.

\subsection{Saran}

Saran yang dapat diberikan adalah :

1. Bahwa dalam pembinaan karier dan menjaga netralitas Pegawai Negeri Sipil, maka pengangkatan Pegawai Negeri Sipil dalam jabatan struktural sekretaris daerah provinsi yang merupakan jabatan tertinggi di daerah provinsi harus dilakukan secara terbuka dengan persyaratan serta mekanisme harus berpedoman pada UndangUndang Nomor 5 Tahun 2014 tentang
Aparatur Sipil Negara.

2. Bahwa sampai saat ini belum diterbitkan peraturan pemerintah sebagai peraturan pelaksanaan dari Undang-Undang Nomor 5 Tahun 2014 tentang Aparatur Sipil Negara, maka demi adanya kepastian hukum dalam pengangkatan jabatan sekretaris daerah perlu segera diterbitkan peraturan pemerintah sebagai peraturan pelaksanaan dari Undang-Undang Nomor 5 Tahun 2014 tentang Aparatur Sipil Negara dan bagi Pegawai Negeri Sipil yang bertindak tidak netral dalam pemilihan kepala daerah dan wakil kepala daerah agar dikenakan sanksi yang tegas sesuai dengan peraturan perundang-undangan yang berlaku.

\section{DAFTAR PUSTAKA}

Hartini, Sri Setajen Kadarsih dan Sudrajat Tedi, 2010, Hukum Kepegawaian di Indonesia, Sinar Grafika, Jakarta.

Anonim, 2013, Pedoman Penulisan Usulan Penelitian Tesis dan Penulisan Tesis Program Studi Magister (S2) Ilmu Hukum, Program Studi Magister (S2) Ilmu Hukum Program Pascasarjana Universitas Udayana.

Jimly Asshiddiqie, 2010, Konstitusi dan Konstitusionalisme Indonesia, Sinar Grafika, Jakarta.

Sunarno Siswanto, 2012, Hukum Pemerintahan Daerah, Sinar Grafika, Jakarta.

Ellydar Chaidir, 2008, Sistem Pemerintahan Negara Republik Indonesia, Pasca Perubahan Undang-Undang Dasar 1945, Total Media, Yogyakarta. 
Busrizalti, H.M, 2013, Hukum Pemda, Otonomi, dan Implikasinya, Total Media, Jakarta.

Hartini, Sri Setajen Kadarsih dan Sudrajat Tedi, 2010, Hukum Kepegawaian di Indonesia, Sinar Grafika, Jakarta.

Mukti Fajar Nd \& Yulianto Achmad, 2010, Dualisme Penelitian Hukum Normative \& Empiris, Pustaka Belajar.

Johny Ibrahim, 2011, Teori dan Metode Penelitian Hukum Normatif, Banyumedia Publishing, Malang.

SF. Marbun dan Moh. Mahfud MD, 2009, Pokok-Pokok Hukum Administrasi Negara, Liberty, Yogyakarta.

Anwar C, 2011, Teori dan Hukum, Konstitusi, Paradigma Kedudukan dalam UUD 1945 Implikasi dan Implementasinya pada Lembaga Negara, Instrans Publishing, Malang.

Dasril Radjab, 2005, Hukum Tata Negara Indonesia, Rineka Cipta, Jakarta.

Undang-Undang Dasar Negara Republik Indionesia Tahun 1945.

Undang-Undang Nomor 5 Tahun 2014 Tentang Aparatur Sipil Negara. 